\title{
Results of eighteen years (2000-2017) monitoring study of an extra-alpine Peregrine Falcon Falco peregrinus population in North- Western Italy
}

\author{
Pier Luigi BERAUdo
}

Received: September 27, 2018 -Revised: October 21, 2018 - Accepted:October 23, 2018

This is a contribution submitted to the Proceedings of the World Conference on the Peregrine Falcon in Budapest in September 2017.

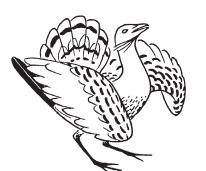

Beraudo, P. L. 2018. Results of eighteen years (2000-2017) monitoring of an extra-alpine Peregrine Falcon Falco peregrinus population in North Western Italy. - Ornis Hungarica 26(2): 130-133. DOI: 10.1515/orhu-2018-0021 con population in Cuneo Province, NW Italy. The first reproduction was recorded in 2000, and from that year, the monitoring work localized 16 occupied territories in an area of $1,900 \mathrm{~km}^{2}$ covering the hills and nearby lowland areas. The average distance between breeding territories was of $7.6 \mathrm{~km}$ with a density 0.7 pairs $/ 100 \mathrm{~km}^{2}$. During the eighteen years, 89 successful breeding attempts were recorded, 81 of them led to fledging of 206 young. Average breeding success was 2.5 juv/reproducing pairs. The nests are located on bridges (motorway viaducts and rail way bridges) and clay/sandstone cliffs. Preliminary prey analyses showed that pigeons and doves represent the $75 \%$ of their diet.

Keywords: Cuneo survey, density, reproduction, nest site, food

Összefoglalás Jelen tanulmányban egy északnyugat-olaszországi vándorsólyom költési adatait közli a szerző Cuneo tartományból. A faj 2000 óta sikeresen költ a hegyekben és a környezö alföldi területeken. A mintegy 1900 $\mathrm{km}^{2}$ területen azóta 16 territóriumot azonosítottak. Az átlagos távolság két territórium között 7,6 km, a denzitás 0,7 pár/100 km². A 18 éves vizsgálat során 89 sikeres költést jegyeztek fel, melyekből 81 esetben összesen 206 fióka repült ki. Az átlagos költési siker 2,54 fióka/költőpárnak adódott. A fészkek főként hidakon, felüljárókon, valamint agyag és homokkőszirteken jellemzőek. Az előzetes eredmények alapján a sólymok táplálékának $75 \%$-át a galambfélék alkotják.

Kulcsszavak: Cuneo tartomány, denzitás, szaporodás, fészkelőhely

Via Monviso 7 -12040 Salmour (Cuneo), Italy,e-mail: igiberaudo@libero.it

\section{Introduction}

In Northern Italy Peregrine Falcon (Falco peregrinus) breeds regularly in the alpine area, with few reported cases in lowland and hilly areas. In the Cuneo province (NW Italy, Piedmont Region) this species is reported nesting in the Alps with 17 pairs (Caula \& Beraudo 2014) and has bred for the first time outside the alpine area in 2000 (Caula et al. 2005, Beraudo \& Toffoli 2009), in the Langhe hilly area. 


\section{Material and methods}

The study area is the lowland and the Langhe and Roero hills, in the Cuneo province (Figure 1). The breeding area (about 1,900 $\mathrm{km}^{2}$ ) is the central north-eastern of the Province, between the Stura di Demonte river valley and the eastern boundary of the Langhe hills (Figure 1). From 2000, a research was started, extended on lowland and the hilly areas of Langhe and Roero with the aim to discovering new occupied territories. A territory was considered as occupied if two individuals of different sex were present, of which at least one adult, and observed in territorial defense and courtship activities (Newton 1979). The monitoring of the reproductive biology (Cheylan 1981) was done between February and July of each year. A couple was considered reproductive when he has successfully bred at least one young. The mean territory distance was calculated by the nearest-neighbour-distance method (Penteriani \& Pinchera 1995). Non-systematic data collection has been allowed to gather some information on prey.

\section{Results}

Between 2000 and 2008, 11 occupied territories were found (Beraudo \& Toffoli 2009), whereas 5 new territories were identified between 2009 and 2017, amounting a total of 16 occupied sites (Figure 1). Altitudinal range was $200-500 \mathrm{~m}$ a.s.1. In 13 sites (81.3\%), reproduction was recorded at least once. Mean distance between these sites was $7.6 \mathrm{~km}$ (minimum distance $=4.8 \mathrm{~km})$. In the Langhe hills $(\mathrm{n}=7$ breeding sites $)$, nests were on clay and sandstone cliffs, whereas in the plain the nests $(n=6)$ were located on bridges (motorway viaduct and railway bridges. On railway bridges, three cases of use of Raven Corvus corax and Hooded-Crow Corvus cornix nests were observed. One of these breeding sites on

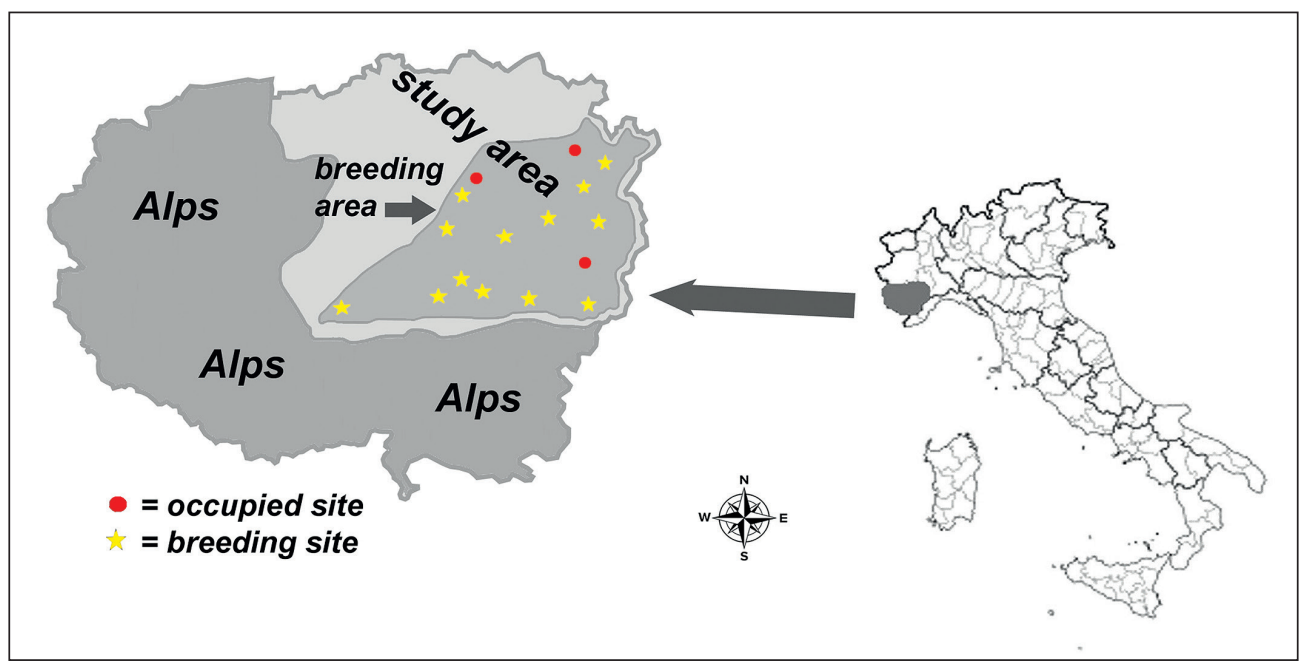

Figure 1. Study and breeding area in Cuneo Province (NW Italy, Piedmont region)

1.ábra A vizsgált terület és a költőhelyek Cueno tartományban (ÉNy-Olaszország, Piemont régió) 
Table 1. Reproductive parameters

1. táblázat Költési adatok

\begin{tabular}{|c|c|c|c|c|c|c|c|c|c|c|c|c|c|c|c|c|c|c|c|}
\hline monitoring years & 응 & 뭉 & ํํํ & @̊ & ষ্ণ & 号 & : & 옹 & $\begin{array}{l}\infty \\
\stackrel{\sim}{0} \\
\end{array}$ & 옹 & 웅 & 둥 & $\frac{\mathfrak{N}}{\mathfrak{N}}$ & m & $\frac{ \pm}{\stackrel{N}{N}}$ & ñ & $\frac{0}{0}$ & 뭉 & 은 \\
\hline $\begin{array}{l}\text { occupied territories } \\
\text { (with adults male and } \\
\text { female) }\end{array}$ & 1 & 2 & 2 & 3 & 4 & 6 & 7 & 7 & 8 & 10 & 8 & 6 & 10 & 7 & 10 & 11 & 11 & 11 & - \\
\hline succesful breeds & 1 & 2 & 2 & 3 & 4 & 3 & 6 & 5 & 3 & 5 & 7 & 3 & 9 & 5 & 8 & 6 & 8 & 9 & 89 \\
\hline $\begin{array}{l}\text { succesful breeds with } \\
\text { fledging juv. number } \\
\text { known (a) }\end{array}$ & 1 & 2 & 2 & 3 & 4 & 3 & 6 & 5 & 3 & 5 & 6 & 3 & 7 & 3 & 5 & 6 & 8 & 9 & 81 \\
\hline fledging juv. (b) & 2 & 4 & 6 & 7 & 8 & 7 & 17 & 13 & 8 & 11 & 14 & 8 & 20 & 9 & 13 & 15 & 21 & 23 & 206 \\
\hline breeding success (b/a) & 2 & 2 & 3 & 2,3 & 2 & 2,3 & 2,8 & 2,6 & 2,6 & 2,2 & 2,3 & 2,6 & 2,8 & 3 & 2,6 & 2,5 & 2,6 & 2,5 & 2,5 \\
\hline
\end{tabular}

bridges has been successfully used for nine consecutive years (2006-2014). A nesting site, located on three different cliffs distributed along $1.7 \mathrm{~km}$ of a river valley, has been continuously occupied from 2000 to 2017. During this period 16 successful breeding attempts have been recorded. In another breeding site occupied since 2005, after the construction of a touristic trail in close proximity of the nest, breeding attempt has been recorded for nine years (2009-2017) even if during 8 years reproduction failed due to human disturbance. During the eighteen years, 89 successful breeding were recorded, 81 of these have led to fledging of 206 young. Average breeding success was 2.5 (Table 1). The fledging date is known for 58 broods and is between the first decade of May and the third decade of June, with maximum peak in the third decade of May.

\section{Discussion}

The studied breeding population, which has probably been originated by the dispersion of individuals from the neighbouring alpine population, is still increasing in this hilly area. In fact, two new breeding pairs have been found between 2015 and 2017. Moreover, two additional breeding sites (one of them occupied since 2012) have been located in the nearby Asti province (Barberis \& Gallo Orsi pers. comm.). However, in the lowland, it seems that the expansion of the Peregrine has stopped, probably because all the available nesting sites (mainly motorway viaducts and railway bridges in river valleys) have been filled by breeding pairs. Due to the local high density of some of the potential preys (author's unpublished data), I suggest that the availability of food may be one of the crucial factors behind the high density and reproductive outputs of this breeding population. Preliminary prey analyses (n $=270$ items) showed that pigeons and doves $(\mathrm{n}=203)$ represent the $75 \%$ of peregrine food, with Feral Pigeon Columba livia and Collared Dove Streptopelia decaocto representing respectively the $49 \%$ and $38 \%$ of total of predated Columbiformes. 


\section{Acknowledgements}

I want to thank V. Barberis, F. Blangetti, G. Boano, B. Caula, U. Gallo Orsi, V. Penteriani.

\section{References}

Beraudo, P. L. \& Toffoli, R. 2009. Espansione del Falco pellegrino, Falco peregrinus, in provincia di Cuneo (Piemonte) ed ecologia riproduttiva della popolazione nidificante nell'area extra alpina [Expansion of Peregrine Falcon, Falco peregrinus, in the Province of Cuneo (Piedmont, Northern Italy) - and breeding ecology in extra-alpine area]. - Rivista Italiana di Ornitologia, Milano 79(1): 3-10. (in Italian)

Caula, B., Beraudo, P. L. \& Toffoli, R. 2005. Gli uccelli della provincia di Cuneo [Birds of Cuneo Province]. - Museo Civico Craveri di Storia Naturale, Bra (in Italian)

Cheylan, G. 1981. Rapaces Mediterraneens [Mediterranean Raptors]. - Parc Naturel Regional de la Corse \& Centre de Recherche Ornithologique de Provence, Aix en Provence (in French)

Caula, B. \& Beraudo, P. L. 2014. Ornitologia Cuneese. Indagine bibliografica e dati inediti [Cuneese Ornithology. Bibliographic survey and unpublished data]. - Primalpe Edizioni, Cuneo (in Italian)

Newton, I. 1979. Population Ecology of Raptors. - T \& AD Poyser, Berkhamsted

Penteriani, V. \& Pinchera, F. 1995. Proposta di standardizzazione del metodo di definizione della densità delle popolazioni di rapace diurni e notturni [Proposal for standardization of the method for defining the density of populations of diurnal and nocturnal birds of prey]. - Supplemento Ricerche Biologia della Selvaggina 22: 159-160. (in Italian)

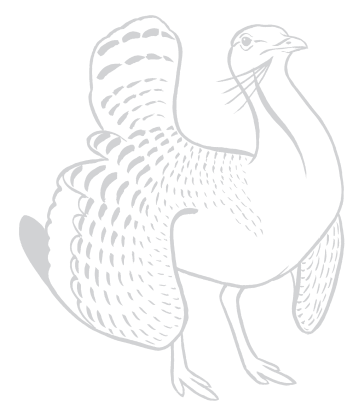

